Proc. Estonian Acad. Sci. Biol. Ecol., 2006, 55, 2, 108-122

\title{
Radial growth of conifers in regions of different cement dust loads
}

\begin{abstract}
Henn Pärn
Department of Ecophysiology, Institute of Forestry and Rural Engineering, Estonian Agricultural University, Viljandi mnt. 18B, 11216 Tallinn, Estonia; hennp@rmk.ee

Received 9 December 2005, in revised form 28 February 2006

Abstract. The climate-growth relationships and the variation of the radial growth of OxalisMyrtillus-site type Norway spruce and Scots pine stands in conditions of different cement dust loads were investigated. The climate-growth relationships were studied during the period from 1946 to 2004. The variation of the mean tree-ring width was studied during three time periods, from 1941 to 1965, from 1966 to 1991, and from 1992 to 2004, characterized by different dust pollution loads. For the investigation of the variations in radial growth during the succeeding time periods the average tree-ring widths were computed for each time period and these were compared with the average ring width in the first, 1941-1965 period. Dendrochronological methods were used. Two study sites, Kunda ( $2.5 \mathrm{~km}$ east of the emission source) and Malla (5.0 km east), are directly influenced by the dust emissions of a cement plant. Other two study sites, Eru ( $38 \mathrm{~km}$ west) and Revoja (34 km west), are situated on a relatively unpolluted area and served as control sample sites. The relationships between the radial growth and climate were almost similar on control and dust polluted sites. The climatic variables that had a significant effect on the radial growth of Norway spruce at both control and polluted sites were the temperature and precipitation of summer months of the current and preceding years. The pine stands growing under dust pollution were characterized by a significant positive impact of the current summer temperature on the radial growth. No precipitation variable having a significant effect on the radial growth of pines at all sites was found. The cement dust emissions had a small negative effect on the radial growth of spruce stands. A significant negative effect of the cement dust on the radial growth of pine stands during the period of large amounts of dust emission (1966-1991) was detected. The decrease in the dust emissions from 1992 improved the growth conditions at pine stand sites.
\end{abstract}

Key words: Norway spruce, Scots pine, dust pollution, climate, radial growth.

\section{INTRODUCTION}

In the industrial region in North-East Estonia alkaline dust pollution from oil shale processing, building materials industry, and power engineering requires special attention as here dry deposition constitutes on average as much as 45 $50 \%$ of the total air pollution (Mandre, 1995a). The effect of dust emitted by the 
building materials industry on plants may be neutral, stimulating, or toxic depending on the type, concentration of components, level of deposition, and meteorological conditions (Kafmierczakowa, 1975; Braniewski \& Chrzanowska, 1988). Most studies on dust effects have revealed a deleterious effect of dust on vegetation. Usually the physical injuries to leaves, chlorotic needles, cell destruction, and reduced growth were observed (Czaja, 1962; Bohne, 1963; Manning, 1971; Singh \& Rao, 1981; Mandre et al., 1994).

Dust deposition has also been found to have a positive effect on the growth of conifers. Havas \& Huttunen (1972) reported a clear increase of radial growth of Scots pines of different age in forests surrounding the fertilizer plant of Typpi Oy in Oulu, Finland. The analysis of the relationships between oil shale fly ash emissions and radial growth of trees indicated that annual radial growth of Scots pines might be influenced positively by oil shale fly ash (Pärn, 2002a). However, the authors admitted the dependence of the pollution-growth relationships on prevailing winds, distance from sources, and chemical composition of pollutants. Some authors have recommended cement-kiln dust as a fertilizer or neutralizer of acid soils (Gissinger, 1957; Hiis, 1974).

The cement plant in Kunda started operation in 1871. As result of the modernization and enlargement of the plant, its production capacity increased gradually up to World War II (Kunda Nordic/Heidelberg Cement Group, 2004). During the war and in the post-war years the plant operated at low capacity. Since the early 1960 s, after the stage-by-stage thorough renovation of the plant, its annual production capacity increased up to 1.24 million tonnes of cement (Vainlo, 1999). Because of the reduced demand for cement after the disintegration of the Soviet Union, the production decreased notably in 1992. The same year the Kunda Nordic Cement was established, and cement production started to increase again.

The cement production process is accompanied with the emissions of considerable amounts of dust. In the late 1980s and early 1990s, the annual emissions of cement dust reached about 100000 tonnes (Vainlo, 1999). After the installation of the electrical precipitators in 1996, the amounts of dust emissions have decreased continuously being e.g. in 2003 slightly less than 170 tonnes (Kunda Nordic/Heidelberg Cement Group, 2004).

Dust pollution causes changes in the growth conditions of forest trees. Dust falling from the atmosphere to the forest ecosystem is deposited mostly on leaves. If an arid period during the growth season lasts for a long time, a crust forms on needles under a high dust pollution load. In the incrusted needles the quality and quantity of light absorption are changed. Light shortage under the dust cover, decrease in the diurnal fluctuation of temperature, and irregularities in transpiration cause disorders in physiological processes connected with assimilation in leaves. The results of an experiment with Scots pine seedlings demonstrated a 25\% lower starch content in trees with incrusted needles and the inhibition of the translocation of carbohydrates into roots and the stem (Mandre, 1995b). Cement dust contains many components $\left(42.48 \% \mathrm{CaO}, 2.74 \% \mathrm{MgO}, 7.82 \% \mathrm{~K}_{2} \mathrm{O}\right.$, and $\left.13.52 \% \mathrm{SiO}_{3}\right)$ that cause alkalization followed by imbalanced nutrition, changes in the plant 
metabolism, and secondarily by a decrease in bioproduction (Rauk, 1995; Mandre, 2000).

During the last 10-15 years the environmental situation in the study area has altered noticeably due to the decreased dust emissions from the Kunda cement plant. The ultimate goal of this study was to provide information about responses of radial growth of conifers growing under diverse levels of cement dust deposition using dendrochronological methods. The specific objectives were:

1. To determine the changes in the radial growth of trees during the various time periods characterized by different dust loads.

2. To compare significant underlying relationships between climatic variables and radial growth of trees under different cement dust loads in order to clarify whether the observed changes in the radial growth are caused mainly by different cement dust loads or whether there exists an essential climatic impact at sites as well.

\section{MATERIAL AND METHODS}

\section{Study area}

Four sample sites in Oxalis-Myrtillus-site type Scots pine (Pinus sylvestris L.) and Norway spruce (Picea abies (L.) H. Karst.) forest stands, located at different distances from the Kunda cement plant, were chosen for investigation in 2005. Among them two study sites, Kunda $(2.5 \mathrm{~km}$ east of the emission source) and Malla (5.0 km east), are directly influenced by the dust emissions of the plant. The other two study sites, Eru (38 km west) and Revoja ( $34 \mathrm{~km}$ west), are situated on a relatively unpolluted area in Lahemaa National Park and served as control sample sites.

All stands chosen for investigation were well stocked. No visible disturbances (insect attacks, wind-throw, etc.) and management history are known for any sampled stands. At the Kunda site the Scots pine stand is 90 years of age and the Norway spruce stand is 85 years of age. At the Malla site the age of stands is 85 and 100 years, respectively. The age of the Scots pine stand at the Eru site is 85 years and the age of the Norway spruce stand is 105 years. At the Revoja site both stands are 80 years of age.

\section{Sampling and measurements}

At each of the four study sites 10-15 dominant or co-dominant trees without visible damage or defect were sampled for analysis of the radial growth. Each sample tree was cored at breast height on the southern side of the bole using a $4.3 \mathrm{~mm}$ increment corer. In laboratory each core, when dry, was mounted onto a grooved holder and the surface of the cores was cleaned and finished using sandpaper. The cores were cross-dated with each other by regional pointer years 
to identify missing or false rings. The widths of tree-rings on cores were measured to the nearest $0.01 \mathrm{~mm}$ with a tree-ring measuring system (Metronics Quick-Chek QC-1000M-AR digital readout unit and a $0.001 \mathrm{~mm}$ resolution Accu-Rite linear encoder). Cross-dating quality was assessed using the COFECHA program available in the Dendrochronology Program Library (DPL) version 2.1 (Holmes, 1983). The trees with cores that were impossible to cross-date or poorly correlated with others were eliminated from further analysis.

\section{Standardization}

Time series of ring-width measurements from individual trees generally contain long-term non-climatic fluctuations, which are associated with increasing tree age. For the investigation of the tree-ring-climate relationships this non-climatic signal must be removed from tree-ring time series (Fritts, 1976; Cook et al., 1990). Standardization transforms ring widths into a new series of relative tree-ring indices. This is achieved by means of a procedure called standardization. Standardization procedure involves the fitting of e.g. an exponential or a low-order polynomial to the time series of the measured tree-ring widths and producing a transformed ring-width series by dividing the raw data by the fitted curve. In dense forests growth curves are complex and variable among trees due to competition between trees. In such cases the application of stochastic methods of standardization (smoothing splines, autoregressive-moving average models) is appropriate (Cook et al., 1990). In this work, standardization was accomplished with the ARSTAN program version 6.04P in DPL. The series of raw ring data were detrended with negative exponential or with $67 \% \mathrm{n}$-spline. The ARSTAN versions of master chronologies for each study site were computed. The ARSTAN chronologies contain the strongest climatic signal possible.

\section{Statistical analysis}

The relationships between the radial growth of trees and climate were estimated applying correlation analysis. The climate-growth relationships were studied during the period from 1946 to 2004 . The starting year of the period is determined by the availability of the climate data. Relationships between the tree growth and climate were estimated comparing the site index chronologies with mean monthly temperatures and total precipitation from the previous June to the current July. The climate data of the previous year were included in the analysis because the climate of the preceding growth session influences the tree growth in the current year (Fritts, 1976). The analysis was accomplished with the STATGRAPHICS program version 5.0.

For the investigation of the variations in radial growth during the succeeding time periods the average tree-ring widths were computed for each time period. In order to assess the variation, the ring width averages of different periods were 
compared with the average ring width in the first, 1941-1965 period. As a result, the percent of decrease was found for each period and for each site. The research hypothesis about the expected differences between the average tree-ring widths in different time periods was statistically tested by Student's $t$-test. Analyses were performed with Excel 5.0 (Microsoft Corp., USA).

\section{Climate data}

The monthly average temperatures and monthly total precipitation data were collected from Kunda meteorological station of the Estonian Institute of Meteorology and Hydrology.

\section{RESULTS AND DISCUSSION}

\section{General trends of the radial growth of stands}

The radial growth of stands is shown in Fig. 1. To better visualize the growth trends of the stands in different time periods, the series of the tree-ring widths were smoothed by the seventh-order polynomial.

\section{Scots pine stands}

The radial growth of pines at the Eru site has a classical shape of the growth curve, which is commonly described by a negative exponential (Fritts, 1976). Against the background of the general decrease in radial growth, the wide treerings in 1946, 1972-1975, and 1988-1990 and the narrow tree-rings in 1956 and 1982-1984 may be distinguished. Starting from 2000 the radial growth showed a declining tendency.

The radial growth of pines at the Revoja site had an upward trend from 1958 until 1980 followed by a tendency of declining up to 1998. After this minimum an increase in the radial growth can be observed. The favourable conditions for tree growth at this site occurred obviously in 1980 and 1986-1990. In 1985 the growth of trees was suppressed.

The radial growth of pines of the Kunda stand follows the classical shape of the growth curve as well with a slightly increasing trend starting from 2000. A sharp increase in the radial growth in 1943-1945 due to favourable temperature and precipitation conditions of these years can be observed. Wide tree-rings in these years are visible in many pine tree-ring chronologies in Estonia (Lõhmus, 1992a; Pärn, 2002b, 2003). Wide tree-rings occurred in 1975-1976 and 1999 as well.

A relatively stable radial growth of pines at the Malla site in 1961-1976 after the decline during the preceding years may be distinguished on the plot. During the next years the radial growth decreased gradually up to 1990 . Thereafter the 
Scots pine

Eru

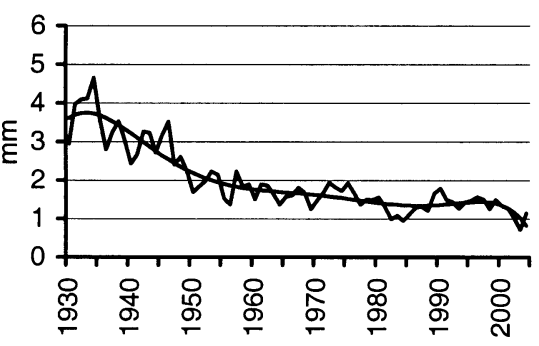

Revoja

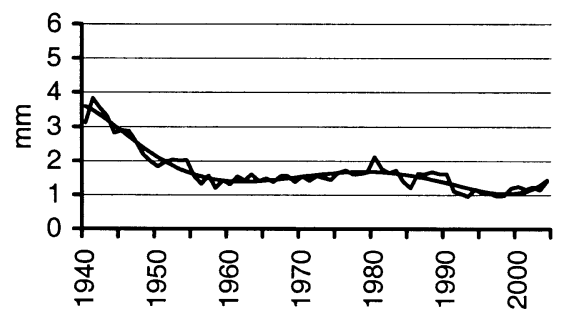

Kunda

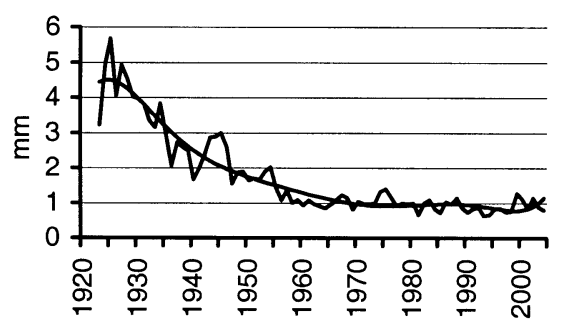

Malla

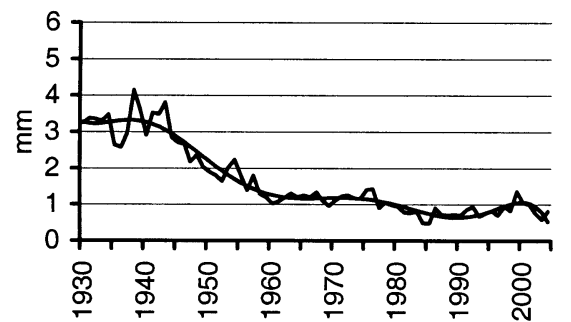

Norway spruce

Eru

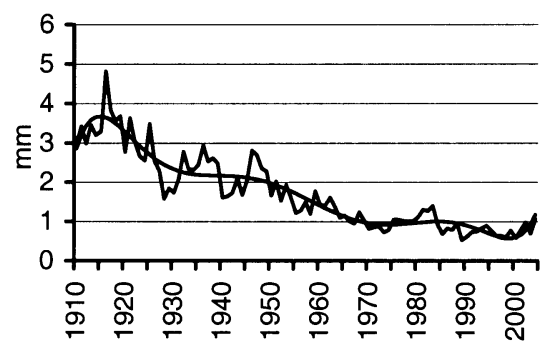

Revoja

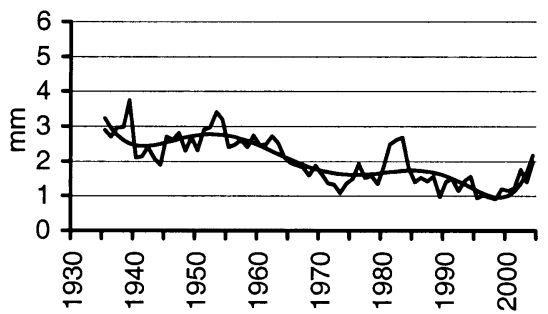

Kunda

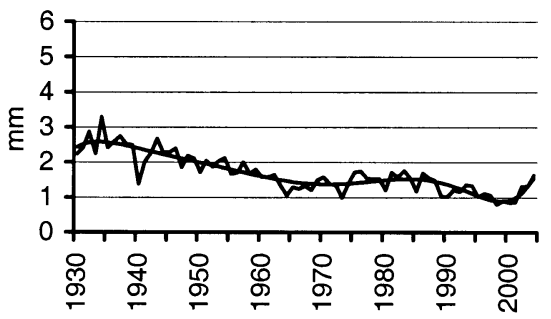

Malla

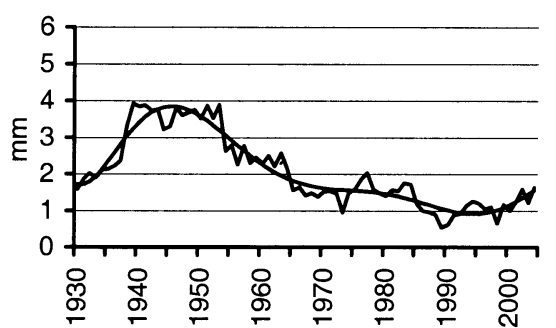

Fig. 1. Radial growth and smoothing curves (seventh-order polynomials) of stands. 
radial growth increased to a next maximum in 1999 followed by the declining trend of the tree-ring widths during the recent years. An increase in the radial increment in 1943-1946 and 1975-1976 can be observed in the plot of ring widths for this study site as well.

\section{Norway spruce stands}

On the plot demonstrating the radial growth of pines of the Eru stand a series of narrow tree-rings near the pith can be observed. The increasing growth capacity during the following years had given rise to the radial growth of trees up to 1916 when the tree-ring widths gained the maximum values. Thereafter the radial growth decreased gradually to a minimum in 1999 followed by a slightly upward trend. Against the background of the general decrease in radial growth, the wide tree-rings in 1936 and 1946 and the narrow tree-rings in 1928-1930 and 1940-1944 may be distinguished.

The growth curve of Norway spruces at the Revoja site is rather complex indicating the variable growth conditions of trees at this site. The generally declining growth trend has several maximums and minimums. The maximum values of the radial growth were achieved in 1939, 1953, and 1981-1983. We still have no data for the reasonable argumentation of the short-term increase in the radial growth in 1981-1983. A good radial growth in these years was detected on the plots of spruces on the other sites, but it was not so remarkable. This suggests that the favourable meteorological conditions had a certain effect on the radial growth of trees in these years. Growth was suppressed in the years 1940-1944, 1970-1972, and 1999. The narrow tree-rings in 1940-1944, which are visible in many treering chronologies in Estonia and in neighbouring areas, can be attributed to the synergetic effect of the very dry summer in 1939 and the frosty winter of 19391940 (Lõhmus, 1992b). Starting from 1999, a sharp upward trend of the radial growth is observed on the plot.

A specific feature of the radial growth of pines at the Malla site is a sharp increase starting in 1939. A series of wide tree-rings can be observed up to 1952 , followed by a sharp decline in the next year and in 1963-1966. An increase in the radial growth in 1939 and 1953 was visible in the plot of ring widths of the Revoja spruce stand as well but with a deep depression in the radial growth between these years. From 1998 the radial growth showed an increasing growth capacity referring obviously to the improved growth conditions. Wide tree-rings were observed also in 1977 and 1981-1984. Growth was suppressed in the years 1973 and 1990-1991.

A period of the good growth of trees from 1974 until 1987 can be observed on the plot for the Kunda site. The radial growth during this period is characterized by high variability. The minimum value of the radial growth occurred in 1999 . After this minimum follows a sharp increase in the radial increment due to more favourable growth conditions. The narrow tree-ring in 1940 can be clearly distinguished on this plot. 


\section{Climate-growth relationships}

The goal of the radial growth-climate relationship analysis in this study was to investigate the differences of these relationships under different dust load conditions.

Previous analyses made by Lõhmus (1992b) identified positive relationships between annual growth of Scots pine and the temperature of the winter prior to the growth season and a negative effect of the warm periods during the latter part of the previous summer and autumn on the radial growth. The water supply in soils has been reported to be sufficient for the growth of Myrtillus-site type stands during the whole vegetation period (Raid, 1968). Water deficit may occur only in droughty summers. For that reason the relationships between precipitation and radial growth of pines were relatively weak compared to the temperature relationships. Recent studies (Pärn, 1996, 2002b) support these results. Significant positive relationships between the radial growth and total precipitation in previous June and August were detected on some sites, however.

We still have no data about the radial growth-climate relationships for Norway spruce in Estonia. The results of a study by Mäkinen et al. (2002), carried out in Norway spruce stands across a transect in Central Europe and Scandinavia, showed different relationships between radial growth and climate variables in different regions. In eastern Germany the current summer precipitation was positively and temperature negatively correlated with increment indices at lower altitudes. In southern Norway year-to-year variation of the radial increment was positively correlated with temperatures of the current spring and summer and negatively related to the current summer precipitation. In Finland, the current summer temperature, especially the June temperature, was significantly correlated with radial growth. The effect of precipitation was less pronounced than the effect of air temperature.

In the present study the relationships between the radial growth of spruces and temperature were almost similar on the control and dust polluted sites (Table 1). The increment indices were negatively correlated with the temperatures of the summer months of the current and preceding years and positively correlated with the spring temperatures. The radial growth of pines was positively correlated with the winter and early spring temperatures at all sites, but these relationships were not statistically significant at the Revoja and Malla sites. The effect of temperatures of the previous late summer months was negative and significant at the control sites but not significant at the Kunda and Malla sites. The analysis revealed a significant positive effect of the current summer temperature on the radial growth of pines growing under dust pollution.

Relationships between precipitation and the radial growth of pines were relatively weak. The detected significant correlations were irregularly distributed between sites. The strong positive impact of precipitation on the growth of pines influenced directly by the dust emissions of the Balti Power Plant in Narva-Jõesuu (Pärn, 2003) was not detected in this case. At sites influenced by the dustemission 


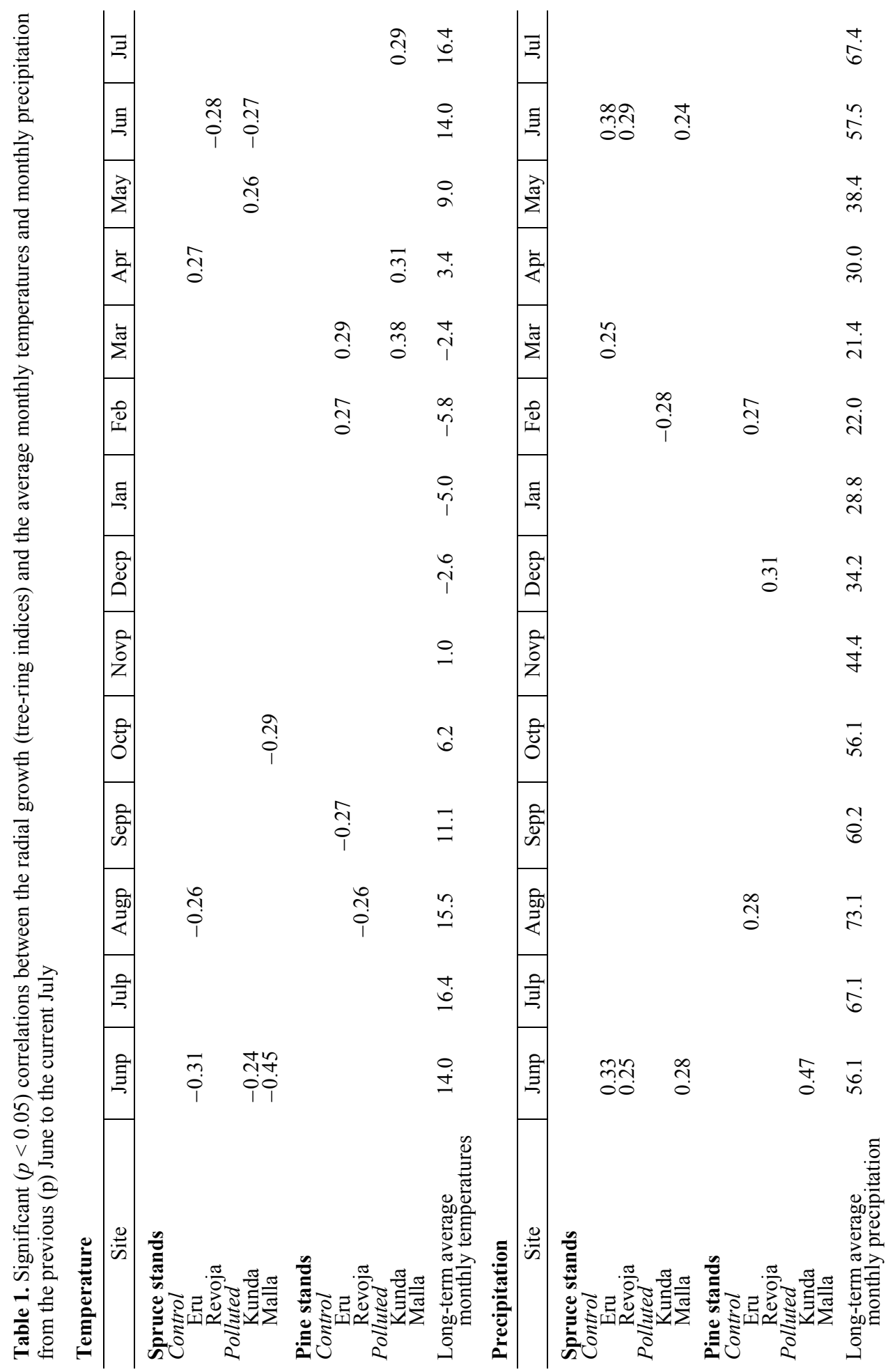


of the cement plant only the precipitation in the June of the previous year had a significant positive effect on the radial growth of pines at the Kunda site.

Contrary to the pine stands, a positive correlation of the increment indices of the spruce stands with the precipitation of summer months of the current and previous years was detected at all sites but the Kunda site. Though the water supply in soils is generally sufficient for the growth of Myrtillus-site type stands during the vegetation period, a certain water deficit for spruce stands may occur in droughty summers. The higher sensitivity of spruce stands to the summer precipitation may be caused by the greater water loss by transpiration per ha than that of pine stands (Schmidt-Vogt, 1987).

\section{The variation of the radial growth during different time periods}

The decrease in the tree-ring width is a normal growth pattern and is associated with increasing tree age. This process may be irregular because of the possible variations in competition between trees and in growth conditions. Significant changes in radial growth of different duration may be caused e.g. by insect attacks (Alfaro \& MacDonald, 1988), atmospheric conditions (Becker et al., 1994), climate change (Cook \& Johnson, 1989), and forest management activities such as thinning (Tullus, 1992), drainage, and fertilization (Pikk, 2003). Rauk (1995) showed a distinct fall in the radial increment of stands at sites where the amounts of cement dust emissions were particularly great.

The variation of the mean tree-ring width was studied during three time periods, from 1941 to 1965, from 1966 to 1991, and from 1992 to 2004, characterized by different dust pollution loads. In 1941-1965 the dust emissions were low or moderate. During the time period from 1966 to 1991 the production of cement and concurrent dust emissions increased rapidly after the reconstruction of the plant in the early 1960s and reached the maximum volumes in 1991. The time period from 1992 to 2004 is characterized by relatively low dust emissions.

\section{Norway spruce stands}

Among the spruce stands a considerable reduction in the average tree-ring width during the period from 1966 to 1991 was detected in both control (Eru) and dust polluted (Malla) stands (Table 2). Obviously the decrease in the radial growth of these stands during this period was mainly connected with the natural decline of the growth curve at this age. The higher percentage of the decrease in the case of the Malla stand is mainly explained by the considerably larger average tree-ring width in 1941-1965. The $t$-test did not show any significant differences in average tree-ring widths between these stands during the first and the second period (Table 3 ). The decrease in the average tree-ring widths of the younger stands at Revoja and Kunda was less than in the case of the older stands. It is noteworthy that the radial growth of the stand at the Kunda site decreased less 
Table 2. Average tree-ring widths and rate of decrease (\%) in relation to the average tree-ring width in the 1941-1965 period of stands in different time periods

\begin{tabular}{c|c|c|c|c|c}
\hline Site & $1941-1965$ & $1966-1991$ & Decrease, \% & $1992-2004$ & Decrease, \% \\
\hline $\begin{array}{l}\text { Spruce stands } \\
\text { Control }\end{array}$ & & & & & \\
$\quad$ Eru & 1.725 & 0.927 & 46.3 & 0.751 & 56.5 \\
$\quad \begin{array}{l}\text { Revoja } \\
\text { Polluted }\end{array}$ & 2.535 & 1.606 & 36.6 & 1.292 & 49.1 \\
$\quad$ Kunda & 1.887 & 1.394 & 26.1 & 1.083 & 42.6 \\
$\quad$ Malla & 3.041 & 1.332 & 56.2 & 1.183 & 61.6 \\
$\begin{array}{l}\text { Pine stands } \\
\text { Control }\end{array}$ & & & & & \\
$\quad$ Eru & 2.175 & 1.477 & 32.1 & 1.256 & 42.3 \\
$\quad$ Revoja & 2.068 & 1.495 & 27.7 & 1.152 & 44.3 \\
$\begin{array}{l}\text { Polluted } \\
\text { Kunda }\end{array}$ & 1.662 & 0.961 & 42.2 & 0.931 & 44.1 \\
$\quad$ Malla & 1.991 & 0.946 & 52.5 & 0.893 & 55.1
\end{tabular}

Table 3. The levels of significance ${ }^{\mathrm{a}}(t$-test) of the differences of the average tree-ring widths of stands in different time periods ${ }^{\mathrm{b}}$

\begin{tabular}{|c|c|c|c|c|c|c|}
\hline \multirow[t]{2}{*}{ Site } & \multicolumn{3}{|c|}{ Spruce stands } & \multicolumn{3}{|c|}{ Pine stands } \\
\hline & Revoja & Kunda & Malla & Revoja & Kunda & Malla \\
\hline Eru & $\begin{array}{l}\text { 1. n.s. } \\
\text { 2. n.s. } \\
\text { 3. n.s. }\end{array}$ & $\begin{array}{l}\text { 1. n.s. } \\
\text { 2. n.s. } \\
\text { 3. n.s. }\end{array}$ & $\begin{array}{l}\text { 1. n.s. } \\
\text { 2. n.s. } \\
\text { 3. n.s. }\end{array}$ & $\begin{array}{l}\text { 1. n.s. } \\
\text { 2. n.s. } \\
\text { 3. n.s. }\end{array}$ & $\begin{array}{l}\text { 1. n.s. } \\
\text { 2. *** } \\
\text { 3. * }\end{array}$ & $\begin{array}{l}\text { 1. n.s. } \\
\text { 2. *** } \\
\text { 3. ** }\end{array}$ \\
\hline Revoja & & $\begin{array}{l}\text { 1. } * * * \\
\text { 2. * } \\
\text { 3. n.s. }\end{array}$ & $\begin{array}{l}\text { 1. n.s. } \\
\text { 2. ** } \\
\text { 3. n.s. }\end{array}$ & & $\begin{array}{l}\text { 1. n.s. } \\
\text { 2. }{ }^{* * *} \\
\text { 3. } * * *\end{array}$ & $\begin{array}{l}\text { 1. n.s. } \\
\text { 2. *** } \\
\text { 3. * }\end{array}$ \\
\hline Kunda & & & $\begin{array}{l}\text { 1. n.s. } \\
\text { 2. n.s. } \\
\text { 3. n.s. }\end{array}$ & & & $\begin{array}{l}\text { 1. n.s. } \\
\text { 2. n.s. } \\
\text { 3. n.s. }\end{array}$ \\
\hline
\end{tabular}

a n.s. $=$ not significant, $* p<0.05, * * p<0.01, * * * p<0.001$.

b 1: 1941-1965; 2: 1966-1991; 3: 1992-2004.

than that at the control stands, indicating a weak effect of dust pollution. The average tree-ring width of spruces at the Revoja site differed significantly from the average ring widths of spruces at the polluted sites, however. This may be caused by the different radial growth rates during the previous period.

During the period from 1992 to 2004 the average tree-ring width of the control stands at the Eru and Revoja sites decreased almost equally (by $10.2 \%$ and $12.5 \%$, respectively). The relative decrease in the radial growth during this period was higher at the Kunda site exceeding that of the control stands. On the contrary, 
spruces at the Malla site exhibited an improved growth. The differences in the average tree-ring widths of stands were statistically not significant during this period, however.

Cement dust emissions seem to have a small negative effect on the radial growth of spruces if compared with the investigated pine stands. At reasonably low doses the effect may be positive. Earlier a favourable impact of low doses of oil shale fly ash on the radial growth of Scots pines was observed in the vicinity of the oil-shale-fired power plant (Pärn, 2002a). Cement dust acts as a neutralizing agent of the soil acidity and increases the content of mineral nutrients in soil. This effect, if it exists, is more clearly expressed at the Malla site. The decrease in the amounts of the dust emissions during the last period studied has obviously improved the growth conditions at this site.

\section{Scots pine stands}

The relative decrease in the radial growth of pine stands at dust-polluted sites was significantly higher than that in the control stands during the period from 1966 to 1991. The average tree-ring width of pines at the Malla stand was about two times less than that in the previous period. The differences in the average tree-ring widths between the control and cement dust-polluted stands were not significant during the period from 1941 to 1965 but became highly significant during the next period. The relative decrease in the average ring widths during the period from 1992 to 2004 was greater in the control stands. Though the declining growth trend from 1999 was visible in the plot of ring widths of the Malla pine stand, the average ring width decreased during this period only by $2.6 \%$. Because of the increasing ring widths of pines at the Kunda site during the last period, the relative decrease in the average tree-ring widths decreased even less than that at the Malla site.

It was shown above that the climate-growth relationships at the control and polluted sites do not differ markedly. Thus it may be inferred from these results that cement dust had a significant negative effect on the radial growth of pine stands during the period of the large amounts of the dust emission. These findings coincide with the results of the earlier studies made in this region (Rauk, 1995). The rather large dust load and its long-term effect have brought about alkalization of the growth environment. This complicates mineral nutrition and disbalances the content of micro- and macroelements in the organisms. Changes in the primary metabolism and mineral nutrition of trees are accompanied by changes in secondary metabolism and growth processes (Mandre, 1995c). On the other hand, the increased values of different morphometric parameters, such as length and dry matter content of needles and shoots, and density of needles on shoots indicated an improvement in the growth of coniferous trees after 1992 in this region as well (Ots, 2000). Also the positive response of the growth to the decreasing dust pollution loads indicates an essential impact of cement dust on the growth of trees, especially on pines. 


\section{CONCLUSIONS}

The climate-growth relationships and the variation of the radial growth of Norway spruce and Scots pine stands in conditions of different cement dust loads were investigated. Dendrochronological methods were used.

In the present study the relationships between the radial growth and climate were almost similar at the control and dust polluted sites. The climatic variables that had a significant effect on the radial growth of Norway spruce at both control and polluted sites were the temperatures and precipitation of summer months of the current and preceding years. The significant impact of the current summer temperature on the radial growth was specific to the pine stands growing under dust pollution. No precipitation variable having a significant effect on the radial growth of pines at all sites was found.

The cement dust emissions had a small effect on the radial growth of spruces. The negative effect is to a certain extent expressed at the Malla site. The decrease in the amounts of the dust emissions during the last period studied improved the growth conditions at this site. Cement dust had a significant negative effect on the radial growth of pine stands during the period of the large amounts of the dust emission. Also the positive response of the growth of pines to the decreasing dust pollution loads was detected.

\section{ACKNOWLEDGEMENTS}

The research was supported by the Ministry of Education and Research of the Republic of Estonia (project No. 0432153s02) and the Estonian Science Foundation (grant No. 5987). Many thanks to my colleagues for their help in the forest.

\section{REFERENCES}

Alfaro, R. I. \& MacDonald, R. N. 1988. Effects of defoliation by the western false hemlock looper on Douglas-fir tree-ring chronologies. Tree-Ring Bull., 48, 3-11.

Becker, M., Nieminen, T. M. \& Gérémia, F. 1994. Short-term variations and long-term changes in oak productivity in north-eastern France: the role of climate and atmospheric $\mathrm{CO}_{2}$. Ann. Sci. For., 51, 477-492.

Bohne, H. 1963. Schädlichkeit von Staub aus Zementwerken für Waldbestände. Allg. Forst., 18, $107-111$.

Braniewski, S. \& Chrzanowska, E. 1988. Effect of dust from electro-filters of different industrial works on the vegetation. Sci. Papers Krakow Agricult. Acad. Forestry, 18, 146-167.

Cook, E., Briffa, K., Shiyatov, S. \& Mazepa, V. 1990. Tree-ring standardization and growth trend estimation. In Methods of Dendrochronology. Applications in the Environmental Sciences (Cook, E. R. \& Kairiukstis, L. A., eds), pp.104-122. Kluwer Acad. Publ., Dordreht.

Cook, E. R. \& Johnson, A. H. 1989. Climate change and forest decline: a review of the red spruce case. Water Air Soil Pollut., 48, 127-140.

Czaja, A. T. 1962. Über das Problem der Zementstaubwirkung auf Pflanzen. Staub, 22, 228-232.

Fritts, H. C. 1976. Tree Rings and Climate. London, New York, San Francisco.

Gissinger, L. 1957. Fly ash as potash fertilizer. Mitt. Sweiz. Landwirtsch., 5, 129-132. 
Havas, P. \& Huttunen, S. 1972. The effect of air pollution on the radial growth of Scots pine (Pinus sylvestris L.). Biol. Conserv., 4, 361-368.

Hiis, V. 1974. Influence of prime and repeated limings on crop yields depending upon different fertilizing backgrounds. Trans. Estonian Agricult. Acad., 92, 53-64.

Holmes, R. L. 1983. Computer-assisted quality control in tree-ring dating and measuring. Tree-Ring Bull., 43, 69-78.

Kafmierczakowa, R. 1975. Correlation between the amount of industrial dust fall and the lead and zinc accumulation in some plant species. Bull. Acad. Polon. Sci. Biol., 23(9), 611-621.

Kunda Nordic/Heidelberg Cement Group 2004. Environmental Review, No. 13. Kunda.

Lõhmus, E. 1992a. Eesti männikute dendrokronoloogiline üldskaala. For. Stud., 24, 103-120.

Lõhmus, E. 1992b. Hariliku männi radiaalkasvu seostest meteoroloogiliste teguritega. For. Stud., 25, 50-59.

Mäkinen, H., Nöjd, P., Kahle, H.-P., Neumann, U., Tveite, B., Mielikäinen, K., Roehle, H. \& Spiecker, H. 2002. Radial growth variation of Norway spruce (Picea abies (L.) Karst.) across latitudinal and altitudinal gradients in central and northern Europe. For. Ecol. Manage., 171, 243-259.

Mandre, M. 1995a. Study area. In Dust Pollution and Forest Ecosystems. A Study of Conifers in an Alkalized Environment (Mandre, M., ed.), pp. 12-17. Publ. Inst. Ecol., 3. Tallinn.

Mandre, M. 1995b. Effects of dust pollution on carbohydrate balance in conifers. In Dust Pollution and Forest Ecosystems. A Study of Conifers in an Alkalized Environment (Mandre, M., ed.), pp. 78-95. Publ. Inst. Ecol., 3. Tallinn.

Mandre, M. 1995c. Changes in the nutrient composition of trees. In Dust Pollution and Forest Ecosystems. A Study of Conifers in an Alkalized Environment (Mandre, M., ed.), pp. 44-65. Publ. Inst. Ecol., 3. Tallinn.

Mandre, M. 2000. Metsaökosüsteemi hälvetest Virumaa tööstuslikust õhusaastest mõjutatud aladel. For. Stud., 33, 37-64.

Mandre, M., Tuulmets, L., Rauk, J., Ots, K. \& Okasmets, M. 1994. Response reaction of conifers to alkaline dust pollution. Changes in growth. Proc. Estonian Acad. Sci. Ecol., 4(2), 79-95.

Manning, W. J. 1971. Effects of limestone dust on leaf condition, foliar disease incidence, and leaf surface microflora of native plants. Environ. Pollut., 2, 69-76.

Ots, K. 2000. Okaspuude okaste ja võrsete morfomeetriast Kunda tsemenditehase ümbruses. For. Stud., 33, 158-176.

Pärn, H. 1996. The impact of different factors on the increment of Vaccinium-type pine stands in Tallinn. Proc. Estonian Acad. Sci. Biol., 45, 192-200.

Pärn, H. 2002a. Impact of oil shale fly ash emitted from a power plant on radial growth of Scots pine in North-East Estonia. Oil Shale, 19, 307-319.

Pärn, H. 2002b. Relationships between radial growth of Scots pine and climate in the northeastern industrial region of Estonia. For. Stud., 36, 47-61.

Pärn, H. 2003. Growth of Scots pines (Pinus sylvestris) on dunes of Southwest Estonia related to climate. For. Stud., 39, 65-80.

Pikk, J. 2003. Puistute ja puuliikide kohanemine toitumistingimuste muutustele erineva veerežiimi ja troofsusega kasvukohtadel. For. Stud., 38, 58-73.

Raid, L. 1968. Veerežiimist pohla ja mustika kasvukohatüübis. For. Stud., 6, 151-169.

Rauk, J. 1995. Radial increment of trees. In Dust Pollution and Forest Ecosystems. A Study of Conifers in an Alkalized Environment (Mandre, M., ed.), pp. 112-116. Publ. Inst. Ecol., 3. Tallinn.

Singh, S. N. \& Rao, D. N. 1981. Certain responses of wheat plants to cement dust pollution. Environ. Pollut., A24, 75-78.

Schmidt-Vogt, H. 1987. Die Fichte. Vol. I. Verlag Paul Parey, Hamburg, Berlin.

Tullus, H. 1992. The increase of the breast height diameter of middle-aged pine stands after thinning. For. Stud., 24, 92 (in Russian).

Vainlo, A. 1999. Tsemenditootmise võimalikkusest keskkonnanõudeid järgides. Keskkonnatehnika, 1/99, 40-42. 


\title{
Okaspuude radiaalkasv tsemenditolmu saastekoormuse erinevates tingimustes
}

\begin{abstract}
Henn Pärn
On uuritud, kas ja kuidas mõjutavad tsemenditolmu erinevad saastekoormused hariliku männi ja hariliku kuuse radiaalkasvu. Et kindlaks teha kliimategurite mõju võimalik erinevus puude radiaalkasvule tolmusaaste erinevates tingimustes, on uuritud ka radiaalkasvu ja kliima vahelisi seoseid. Uurimispiirkonnaks on valitud tsemenditehase Kunda Nordic Cement piirkond.

Tsemenditolmu mõju radiaalkasvule on uuritud kolme perioodi jooksul: 19411965 (mõõdukas tolmusaaste), 1966-1991 (kõrge tolmusaaste) ja 1992-2004 (madal tolmusaaste). Uurimisobjektideks on valitud jänesekapsa-mustika kasvukohatüübi hariliku männi ja hariliku kuuse puistud neljal proovialal. Vahetu tolmusaaste piirkonnas asuvad Kunda ja Malla prooviala paiknevad tehasest vastavalt 2,5 ja $5 \mathrm{~km}$ kaugusel ida suunas. Kontrollalad Erus ja Revojal paiknevad suhteliselt tolmusaastevabas piirkonnas vastavalt $38 \mathrm{ja} 34 \mathrm{~km}$ kaugusel tehasest lääne suunas.

Eelnenud perioodiga võrreldes vähenes kuuskede keskmine aastarõnga laius perioodil 1966-1991 kõige enam Eru (46,3\%) ja Malla (56,2\%) proovialal. Suhteliselt tagasihoidlik Kunda prooviala kuusiku juurdekasvu vähenemine sel perioodil, võrreldes teiste proovialadega, näitab tolmusaaste vähest mõju kuuskede kasvule. Viimasel uuritaval perioodil (1992-2004) vähenes aastarõngaste keskmine laius kontrollproovialadel ühtlaselt ja suhteliselt vähe (10-12\%). Seega võib järeldada, et tolmusaaste mõju kuusikute radiaalkasvule ei olnud üldine ja tugev, kuigi juurdekasvu paranemine Malla proovialal tolmuemissioonide vähenemise perioodil viitab siiski teatava mõju esinemisele.

Männikute puhul vähenes aastarõngaste keskmine laius Kunda ja Malla proovialal perioodil 1966-1991 oluliselt rohkem kui kontrollaladel. Vastupidi, tolmusaaste tunduva vähenemise perioodil vähenes aastarõngaste keskmine laius oluliselt rohkem kontrollalade männikute puhul.
\end{abstract}

